\title{
Hvordan engasjere suicidale pasienter i mentaliseringsbasert behandling?
}

\author{
Ved Christian Schlüter
}

\begin{abstract}
Mentaliseringsbasert terapi (MBT), utviklet av Anthony Bateman og Peter Fonagy, har vist seg effektiv mht. å behandle personer med ustabil personlighetsforstyrrelse (UPF), og har også vist at bedringen holder seg over lang tid. Avdeling for Personlighetspsykiatri har implementert en variant av det MBT-opplegget som drives i London.
\end{abstract}

\section{ABSTRACT}

Mentaliseringsbasert terapi (MBT), utviklet av Anthony Bateman og Peter Fonagy, har vist seg effektiv mht. å behandle personer med ustabil personlighetsforstyrrelse (UPF), og har også vist at bedringen holder seg over lang tid. Avdeling for Personlighetspsykiatri har implementert en variant av det MBT-opplegget som drives i London. Selvmordsproblematikk av forskjellig art og grad utgjør en vesentlig del av de problemene personer med UPF har. Det er derfor viktig at all psykoterapi med denne pasientgruppen har et fokus på dette, og har et rasjonale for forståelse og håndtering av slike suicidale tilstander. Grunnet det alvorlige i lidelsen, er det viktig å engasjere disse personene i behandlingen slik at de ikke dropper ut, eller at behandlingen skaper forverring.

Artikkelen vil summarisk redegjøre for mentalisering og mentaliseringssvikt, som anses som den patologiske kjerneproblematikken for denne pasientgruppen. Dernest presenteres tre kliniske områder som MBT anser som særs viktige for at behandlingen av suicidale pasienter med UPF skal lykkes. Det dreier seg om 1) forståelse og håndtering av selvmordsrisiko, 2) selve behandlingsopplegget og 3) MBT holdning, fokus og teknikk.

Formålet med artikkelen er å vise hvordan MBT terapeuter arbeider klinisk med denne problematikken, og dermed bidra til at en $\varnothing$ kt forståelse, toleranse og konstruktiv håndtering av disse problemene, vil kunne finne sted.

Mentalization Based Therapy (MBT), developed by Anthony Bateman and Peter Fonagy, has proven effective with respect to treating people with Borderline Personality Disorder (BPD), and has also shown that the improvement remains over time. Department of Personality Psychiatry has implemented a variant of the MBT program. Suicidal behavior of varying degree and nature constitutes a significant part of the problems individuals with BPD have. It is therefore important that all psychotherapy with this group of patients has a focus on such behaviors, and have a rationale for the understanding and management of suicidal states. Due to the seriousness of this aspect of the disorder, it is important to engage these individuals in the treatment to prevent drop out, or that the treatment itself creates aggravation.

The article will summarily describe mentalization and failure to mentalize, which is conside red the pathological core issue for this patient group. Secondly, three clinical areas considered vital in MBT for successful treatment of suicidal patients with BPD are presented; 1) the understanding and management of suicide risk, 2) the treatment program, and 3) MBT attitude, focus and technique.

The purpose of this article is to show how to work clinically with suicidal behavior within an MBT framework, and facilitate an increased understanding, tolerance and constructive management of these problems.

\section{Innledning}

\section{Ustabil PF og suicidalitet}

Selvmordsproblematikken hos personer med ustabil personlighetsforstyrrelse (UPF) er kjent. I det offentlige rom er personer med slike vansker mest kjent for "å ta overdoser med piller, være selvskadende og være i hyppige suicidale kriser" (Paris, 2006). Det alvorlige i lidelsen blir tydelig når forskning har påvist at et sted mellom 50-75 \% av personer med UPF har minst ett selvmordsfors $\varnothing \mathrm{k}$ i løpet av sin sykehistorie, og at dødeligheten ved gjennomf $\varnothing r t$ selvmord for denne gruppen er så høy som 3-10 \% (Mehlum et al., 1994). Konsekvensene av å ha UPF er således omfattende for den det gjelder, i tillegg til de belastninger dette måtte ha for nær familie.

Men hvorfor er selvmordsproblematikken så uttalt hos personer med UPF?

Det er trolig fordi personer med UPF er sterkt relasjonss $\varnothing$ kende, men samtidig også svært relasjonelt sensitive. En mer presis betegnelse for denne sensitivitet vil være «en forstyrrelse i den interpersonlige relaterthet» (Skodol et al., 2006), og at det er denne karakteristiske relasjonsforstyrrelsen som atskiller UPF både fra personer som ikke har PF, og i forhold til de andre personlighetsforstyrrelsene hvor relasjonsvanskene arter seg på en annen måte (McWillams, 2011).

Dette bekreftes også gjennom forskning som har påvist at mellommenneskelige stressfaktorer ofte kommer før selvmordsfors $\varnothing \mathrm{k}$ hos personer med UPF, enn i noen annen lidelse assosiert med depresjon (Brodsky et al., 2006). Årsaken ligger trolig i at personer med UPF ikke bare kommer i relasjonsvansker, men at de også har en redusert evne til interpersonlig problemløsning, spesielt i emosjonelt ladete tilknytningsrelasjoner (Fonagy \& Bateman, 2006a). Personer med UPF blir derfor når de er i relasjoner, stilt overfor den uheldige kombinasjonen av på den ene siden en tilbøyelighet til å oppleve (og aktivt fremkalle) smertefulle problemer i deres forhold til andre, og på den annen side en redusert evne til å inngå i interpersonlig problemløsning. Den smerte disse problemene skaper, sår grunnen for selvmordsproblematikken.

Et eksempel på en slik «forstyrrelse i interpersonlig relaterthet» kan være frykten for tap, frykt for å bli forlatt og frykt for avvisning. Den panikken disse forestillingene medf $\varnothing$ rer, får flere skjebnesvangre konsekvenser. Dels făr den disse personene til å gjøre en del destruktive handlinger, som ofte f $\varnothing$ rer andre lenger vekk fra dem. De får således oppfylt det de frykter mest, og er i en velkjent ond sirkel. I relasjoner med mer destruktive andre kan en se den motsatte effekten. Der vil frykten de føler når andre behandler dem dårlig, $\varnothing$ ke tilknytningsintensiteten til den destruktive andre. Dette skjer fordi evnen til å reflektere er skrudd helt av (Bateman \& Fonagy, 2011). Her vil altså personen kunne bli værende i svært destruktive relasjoner. Selvmordsproblematikk kan være et problem for mange som har psykiske lidelser, og spesielt ved depresjoner eller alvorlige sinnslidelser. Når vi her trekker frem personlighetsforstyrrelser og UPF spesielt, er det fordi personer med disse vanskene i større grad enn andre vil oppleve relasjoner som spesielt vanskelige. Og, når en vet at solide, støttende og tilfredsstillende relasjoner ofte er det som skal til for å få personer med psykiske vansker på fote, skjønner en at disse blir ekstra sårbare. Dette gjelder ikke minst forholdet til de relasjonene de vil stå oppe i, som en del av selve terapien. Det blir gjennom dette forhåpentligvis klart hvorfor det er så viktig å engasjere og håndtere denne pasientgruppen spesielt, slik at behandlingen ikke blir enda et nytt relasjonelt nederlag.

Når vi i det neste skal se nærmere på de teoretiske begrepene mentalisering og mentaliseringssvikt, så skyldes det at 
de er ment å kaste lys nettopp over hvorfor de interpersonlige problemene oppstår. Terapimodellen (MBT), som vi skal se på senere, er en forlengelse av denne forståelsen og er konstruert med det formål å hjelpe personer med å øke mentaliseringsevnen, slik at de får en bedre interpersonlig forståelse, vurdering og problemløsning.

\section{Mentalisering og mentaliseringssvikt}

Mentaliseringsteori i moderne form er utviklet av Peter Fonagy og Anthony Bateman ved Anna Freud-senteret i London. Teorien er et fors $\varnothing \mathrm{k}$ på å integrere mange ulike fagtradisjoner som bl.a. tilknytningsteori, affektbevissthet, theory of mind og nevropsykologi. Siktemålet for teorien er å konstruere en terapi (MBT) som skal hjelpe pasienter med en ustabil personlighetsforstyrrelse (UPF) til å utvikle en st $\varnothing$ rre forståelse for den menneskelige subjektivitet.

Mentalisering er et overordnet begrep om flere underliggende mentale prosesser, som en trenger å ha utviklet for å kunne klare å orientere seg i egen og andres subjektive verden. Evnen til å mentalisere regnes for å være et utviklingspsykologisk anliggende, det vil si noe som kan utvikles i større eller mindre grad (Fonagy, Gergely, Jurist, Target, 2002). Det dreier seg om utviklingen av evnen til å være oppmerksom på, og kunne reflektere over, egen og andres indre mentale tilstand, og å se at egen og andres atferd er motivert av komplekse indre forhold. Det handler derfor dels om selverkjennelse og dels om å kunne vurdere noenlunde korrekt andres motiver og intensjoner, samt å kunne reflektere over interpersonlige hendelser og samspill.

A mentalisere er noe som foregår fra $\varnothing$ yeblikk til фyeblikk, og som utgjør selve den psykologiske forbindelsen mellom to eller flere personer. Overordnet handler det om kommunikasjon; om forståelse og formidling av mening om seg selv, og en søken etter betydningen i de(n) andres eksplisitte eller implisitte uttrykk. Evnen til sosial kognisjon er således nært forbundet med evnen til å mentalisere.
Mentaliseringsevnen anses som god om personen klarer å ta flere forhold i betraktning, skifte perspektiv, være fleksibel og refleksiv, oppklare misforståelser, erkjenne at den andre har en annen subjektiv verden enn en selv, forstå at en selv også påvirker den andre, at kontekst spiller inn etc. Populært sagt handler mentaliseringsevnen om «å kunne se seg selv utenfra og andre innenfra» (Nygren \& Skårderud, 2008). Resultatet av god mentalisering er at en klarer å tenke og føle klart. En intern sp $\varnothing \mathrm{k}$ som begge umiddelbart forstår kan være et eksempel på god mentalisering. Et annet resultat kan være at den andre føler seg forstått, noe som inngir tillit. Et tredje resultat kan være at utfordrende situasjoner og relasjoner, som har et potensiale for sammenbrudd og krise, vil kunne reddes om en makter å mentalisere når følelsesaktiveringen er på topp. Et fjerde resultat kan være at en klarer å stagge en impuls. Med tilgangen på flere perspektiver skapes det også en interpersonlig avstand, gjennom den differensiering som nye og flere perspektiver medf $\varnothing$ rer.

De fleste av oss strever med dette fra tid til annen, og denne ferdigheten er heller ikke statisk, men varierer avhengig av kontekst og hvor ladet relasjonen er. Noen mentaliserer seg selv bra, men andre dårlig, andre motsatt. Vi har alle «vårt» når det gjelder tap av evnen til å mentalisere. Ut i fra et terapiståsted er det den enkelte pasients mentaliseringsprofil som er av interesse.

Denne allmennmenneskelige kapasiteten er ikke noe vi er født med, men noe som vi lærer gjennom gjentatte erfaringer med markert og kontingent speiling i tidlige tilknytningsforhold. Om denne speilingsprosessen, av forskjellige grunner, ikke har gått godt, vil individet senere i livet få problemer med å mentalisere (Fonagy, Gergely, Jurist, Target, 2002). Grunnen til dette skyldes at den utviklingspsykologiske «modellen for tenkning» er dårlig representert, dvs. at personen har lite tilgang til «å tenke tanker om egne og andres tanker og følelser» (op.cit). De har m.a.o. lite indre mental kapital å dra veksler på, når den emosjonelle temperaturen i relasjoner stiger.
Det som da skjer, er at pre-mentaliserende erfaringsmodus tar over. MBT har identifisert tre slike og benevnt disse for «psykisk ekvivalens», «pretend mode» og «teleologisk modus». Når den subjektive og sosiale verden oppleves fra en av disse posisjonene, vil subjektiv erfaring forvrenges, følelsene intensiveres og den sosiale vurderingsevnen lide. Sagt på en annen måte, vil et slikt tap av mentalisering kunne føre til en fragmentert selvoppfatning, problemer med å regulere følelser, impulsivitet, selvdestruktivitet og en trang til å handle. Ved mentaliseringssvikt vil personen altså lettere misforstå andre, og kunne føle seg tvunget til å ta i bruk andre (tvingende) midler for å forstå, regulere og formidle sin egen mentale tilstand. En kan således hevde at god mentalisering virker preventivt på selvmordsproblematikk. Uten å kunne mentalisere er en ekskludert fra å delta i den sosiale verden, noe som ofte er en av hovedgrunnene for suicidale tilstander.

\section{Mentaliseringsbasert terapi (MBT)}

Mentaliseringsbasert terapi (MBT) er den praktiske og kliniske anvendelsen av mentaliseringsteori på personer med UPF. Her anses mentaliseringssvikten som den mest fremtredende patogene kjerne. Hovedproblemet til personer som har en UPF er således at de har vansker med å opprettholde en nyansert mentalisering. Dette henger sammen med en tendens til en overaktivering av tilknytningssystemet. Dilemmaet for disse personene er at når de søker nærhet med andre, så overaktiveres tilknytningssystemet samtidig, noe som gjør dem sårbare for fall i mentalisering. Når dette skjer påvirkes ikke bare selve tankeinnholdet, men også selve evnen til å tenke.

MBT er ikke det eneste strukturerte behandlingsopplegget for personer med ustabil PF. Dialektisk atferdsterapi (DBT), etablert av Marsha Linehan, er et annet behandlingsalternativ (Linehan, 1993). MBT plasserer seg derfor i et mangfoldig teoretisk og klinisk fagfelt og utgjør ett av flere perspektiver en kan anlegge når en skal arbeide med pasienter med UPF. Andre etablerte behandlingsmodeller 
for denne pasientgruppen er Overføringsfokusert psykoterapi (Clarkin, Yeomans, Kernberg, 2006), Skjemafokusert terapi (Young, Klosko, Weishaar, 2003) og Metakognitiv terapi (Di Maggio, Semerari, Carcione, 2007).

Hensikten med denne artikkelen er ikke å gi en samlet oversikt over disse, inkludert forskjeller og likheter i forståelse og tilnærming. Ett eksempel kan likevel nevnes, for å illustrere noe av likhetene og forskjellene mellom DBT og MBT. I all hovedsak deler MBT og DBT synet på at situasjoner som har ledet opp til suicidale tilstander, bør analyseres svært nøye. DBT kaller dette for «kjedeanalyse», og har til hensikt å rette oppmerksomheten mot hvordan pasienten kan endre atferd gjennom læring av nye ferdigheter. MBT har et mer «indre» anliggende og anser suicidale tilstander som motivert ut i fra et behov for å reetablere selvstruktur, etter plutselig destabilisering. MBT vil derfor utforske mulige årsaker til en slik de-stabilisering først, og vil i den prosessen fokusere mer på følelser, tilknytning, interpersonlig

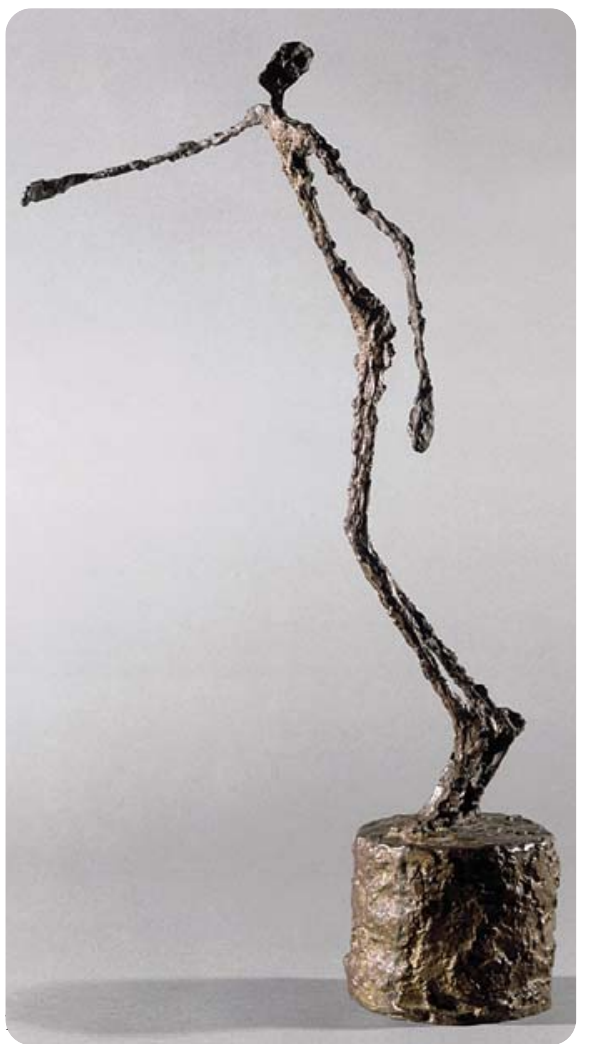

personlige ansvar, enn på mestring. Ved Avdeling for Personlighetspsykiatri har en implementert en MBT-behandlingsmodell. Konkret består behandlingsprogrammet i dag av kombinasjonsterapi (ukentlig individuell og gruppeterapi) i opptil tre år. I tillegg går alle pasientene i en tidsavgrenset psykopedagogisk gruppe (Karterud \& Bateman, 2011), og pårørende får tilbud om egen pårørendeundervisning.

Selve behandlingsopplegget er strukturert i den forstand at den følger nøye oppsatte prosedyrer, har en definert ramme, en klar rollefordeling og er team-basert. Behandlingen er også strukturert i den forstand at den er fokusert på å identifisere og rette opp mentaliseringssvikt som oppstår i forbindelse med at tilknytningssystemet blir aktivert.

En betydelig del av pasientene med UPF som søker seg til MBT-behandling ved vår avdeling, har selvmords-

problematikk (tidligere fors $\varnothing \mathrm{k}$, pågående selvskading eller kroniske selvmordstanker). Videre har de ikke sjeldent hatt mange tidligere terapeuter og/eller droppet ut av tidligere behandlinger. Så hvordan engasjere pasienter med slike relasjonelle problemer og erfaringer, innenfor et MBT-program? Og hvordan motivere dem til å fortsette og å utholde behandlingen? Er det noe spesifikt MBT anbefaler, som også andre modeller kan dra nytte av? Slike sp $\varnothing$ rsmål er særdeles relevante når en vet at selvmordsraten er vesentlig lavere hos denne gruppen, så lenge de befinner seg i en pågående behandling (Paris, 2006).

\section{Hvordan engasjere pasienter med selvmordsproblematikk i mentaliseringsbasert behandling?}

\section{Kartlegging, selvmordsvurdering og risikovurdering}

På lik linje med andre psykoterapeutiske behandlingsmodeller er det første en gjør å finne ut om pasienten har selvmordstanker, og om de er kroniske eller akutte. Noen pasienter har kroniske tanker, uten at de er i en akutt fare, andre motsatt.
Dette er ikke statiske tilstander, for selv personer med lav grad av kroniske tanker vil i løpet av behandlingen kunne utvikle akutte tanker. Unngår en derimot å lage et skille mellom disse, er det en fare for at tiltakene vil kunne skape skadelige effekter, fordi strategiene en bruker ved akutt krise, som f eks. hospitalisering, er uhensiktsmessige ved kronisk risiko (Paris, 2006). Det samme gjelder for overforbruk av medisin, spesialbehandling som en-til-en kontakt og forlengelser av sykehusopphold. Alle disse tiltakene $\varnothing$ ker, ikke minker, den kroniske faren ved UPF (Bateman \& Fonagy, 2006).

$\AA$ skille mellom livstruende akutte kriser og de som ikke er det er ikke lett, men kan forbedres gjennom teamdiskusjon, klinisk erfaring, kjennskap til den individuelle pasient og kunnskap om forløpere til selvmordsrisiko. Ved kroniske selvmordstanker tar en ikke en selvmordsrisikovurdering hver gang, men aksepterer at dette er slik personen har det og har hatt det over år.

Under en slik selvmordsrisikovurdering er MBT positivt innstilt til bruken av strukturerte intervjuer, men bare der utdypingen av de forskjellige aspekter av en suicidal tilstand fremmer mentaliseringsevnen. Det skjer der pasienten får en følelse av at terapeuten tenker på ham og hans sinn (Bateman \& Fonagy, 2011). Bruken av strukturelle intervjuer kan også ha den effekten at det reduserer terapeutens angst, det vil si hjelper vedkommende til å mentalisere bedre. En kan også bruke motiverende intervju (MI) ved "suicidal ambivalens". MBT er opptatt av at bruken av intervjuer, skjemaer o.l. må gjøres i en samarbeidende ånd, hvor en sitter ved siden av hverandre, i motsetning til rett overfor. Den overordnede målsetningen er uansett å få personen med på å utsette selvmord, for å gi behandling en sjanse.

Det som kanskje er spesielt for MBT i en slik tidlig fase, er at en lager en «dynamisk formulering», som i korthet skisserer pasientens problemområder, klargjør fokuset og forhandler frem alliansen for terapien. MBT har også et utpreget pedagogisk siktemål.

Pasienter skal bli forklart eksplisitt hvor- 
dan vi forstår deres mentaliseringsproblemer, hva som skal til for å bedre problemene, hvordan det kan gjøres ved hjelp av behandlingen, samt gevinstene de kan hente ut. Inkludert i dette er også informasjon om at en raskere blir bedre av å gå i behandling, at det finnes håp, og at vi har forskning som kan underst $\varnothing$ tte dette.

Videre må det brukes tid på å engasjere pasienten i en detaljert krise-/sikkerhetsplan, som skal ha en tydelig ansvars- og rollefordeling. Det innebærer bl.a. at en forventer at pasienter kommer med egne forslag til løsninger. Fra et MBT-ståsted antar en at pasienten har evnen til å mentalisere, men at den lett mistes. Fokuset blir på hvilke tanker/følelser som utløses i bestemte situasjoner og som kan føre personen inn i farlige situasjoner.

MBT opererer derimot ikke med en «ikke skade seg-kontrakt». Årsaken er at når pasienten f.eks. er i psykisk ekvivalens, er det meste av det som var avtalt i en annen tilstand "glemt" (Bateman \& Fonagy, 2006a). Det eneste en oppnår om pasienten likevel skader seg, er demoralisering og fare for at pasienten føler at vedkommende har sviktet opplegget. Det en derimot anbefales å gjøre, er å gå gjennom kriseplanen på nytt hver gang det går galt. Her anbefales det vanlige mentaliseringsfremmende spørsmål: «Hvordan og når merket du at du begynte å bli suicidal, og når visste du at kriseplanen ikke kom til å holde?»

Fors $\varnothing \mathrm{k}$ på å engasjere pasienter med selvmordsproblematikk starter gjennom disse eksemplene allerede i begynnelsen av behandlingen. En tar deres problemer på alvor, viser at en er kjent med problematikken og fors $\varnothing$ ker å danne en allianse om hvordan dette kan bli bedre på sikt. En forklarer også siktemålet med terapien og fors $\varnothing$ ker å være så eksplisitt som mulig på hvordan behandlingen vil kunne virke. En fokuserer også på det nødvendige med samarbeid og det personlige ansvar.

\section{Behandlingsopplegget, krisesamtaler, innleggelser}

Et vesentlig poeng når det gjelder selvmordsproblematikk hos personer med UPF, er at selve behandlingsopplegget må være strukturert. Det må være rommende, være klart og tydelig («markert») definert. Selve designet på behandlingen er også viktig. Det gjelder ikke bare teamets sammensetning, teoretiske ståsted og grad av enighet, men også tydelighet med hensyn til hvordan en f.eks. håndterer suicidale kriser. Terapeutene må føle seg trygge og ikke overveldes av for mye angst, og for å oppnå dette anbefales blant annet at alle pasientene er teamets ansvar, at det er tette teamdiskusjoner, at store behandlingsavgjørelser tas av hele teamet, at det er to terapeuter i gruppene og at alle går i veiledning (Rydén \& Wallroth, 2008). Det siste personer med UPF trenger, er behandlere og et behandlingsopplegg som er uoversiktlig, utydelig og nølende. Det kan i noen tilfeller være direkte skadelig med kaotiske og uoversiktlige samarbeidsforhold. Innenfor MBT tenker en seg altså at den overordnede behandlingsstrukturen har en preventiv virkning på selvmordsproblematikken, fordi det virker samlende på pasienten.

Et annet kjennetegn ved MBT er innføringen av terapigrupper. Grunnen til at dette kan virke preventivt på suicidale tilstander, er at en vesentlig risikofaktor for suicidal atferd er «sosial isolasjon, en følelse av å være alene og fremmedgjort» (Joiner, 2005). Mye av dette blir aktivt motarbeidet når en sitter sammen med andre mennesker, deler erfaring og lytter til andre. Ikke minst gir det erfaringer om at suicidale tilstander går over, at det således er håp og at en ikke er alene eller annerledes.

Krisesamtaler tas aktivt i bruk når personen er i suicidale tilstander. Tanken er at disse oppstår fordi personen føler seg «alene og i midten av uutholdelig emosjonell smerte» (Allen, 2006). Følelsen som skapes av å være alene og isolert skyldes i seg selv et fravær av mentalisering, dvs. en manglende følelse av at noen tenker på en. Det viktigste en terapeut gjør i krisesamtaler er nettopp det - å mentalisere personens suicidale tilstand og få personen selv til å gjøre det. En fokuserer på nylige hendelser, og gjerne på noe som har skjedd i behandlingen.
Du foretar videre en «affektanalyse»: «Når var det du begynte å merke deg at du ble suicidal. Hva skjedde, hvem sa hva, hvordan føltes det etc.?»

Krisesamtaler må kunne etableres hurtig, og informasjonen alle pasienter får er at «legger du igjen en beskjed, vil jeg, eller en annen fra teamet, ringe deg tilbake så fort vi får beskjeden». Under samtalen er et annet medlem av staben også gjerne med, i tillegg til den individuelle terapeuten. Responsen på krisen skal komme fra teamet og ikke den individuelle terapeuten. Dette for å minimalisere den mulige risikoen for tilfredsstillelse pasienten kan få via spesiell oppmerksomhet, bekymringer fra staben og ekstra kontakt. Suicidale trusler skal ikke bli valutaen for ekstrakontakt av ymse slag. Hvis en slik dynamikk er i ferd med å utvikles, skal ikke staben handle raskt, arrangere krisem $\varnothing t e r$ eller gi ekstratimer, men tvert imot gi pasienten ansvaret tilbake ved å be vedkommende ta sine suicidale impulser opp i det ordinære behandlingsprogrammet.

Døgninnleggelser skal bare tas i bruk ved akutt risiko der alle andre midler er prøvd. Innleggelser bør sjelden vare mer enn 2-3 dager og ha klare målsetninger, være frivillig, lett tilgjengelig, pasientstyrt, ha definerte grenser og med en planlagt avslutning uansett om tilstanden er blitt forverret. Oppstår forverring er det fordi sykehusinnleggelsen har hatt en skadelig effekt på vedkommende (Bateman \& Fonagy, 2004). Det er derfor svært viktig å følge med på personens respons på bli innlagt, slik at en ikke overstimulerer deres tilknytningssystem. Skjer det, havner en raskt i onde sirkler som gjør at problemene eskalerer. Noen pasienter har også en læringshistorie på at selvmordstrusler «åpner porten», selv om det sjelden er den underliggende intensjonen. På tross av et press om å $\varnothing$ nske seg innlagt, beskriver pasienter med UPF ofte behandlingen på døgnavdelinger som «inadekvat, ineffektiv og utilfredsstillende» (op.cit).

Hele behandlingstilnærmingen bærer preg av «hфyrisiko», og vi tar bare over ansvaret for personens liv hvis personen er akutt og alvorlig i faresonen. 
«Vanlig» kronisk risiko behandles gjennom det ordinære behandlingsprogrammet, og krever ingen spesifikke ekstratiltak. Selvmordsproblematikk ses på som en del av årsaken til at personen befinner seg i behandling. Ansvaret hviler først og fremst på pasienten, og det gjøres klart fra starten av. Ansvarliggjøring handler også om å kunne be pasienten ta overveide valg, selv under kriser. En ser dessverre ofte at eskalerende trusler fører til at staben overtar mer og mer av ansvaret, selv om den kliniske konsensusen rundt selvmordsfare hos UPF viser at jo større ansvar staben tar, jo verre blir pasientens kliniske tilstand (Bateman \& Fonagy, 2004).
Graden av ansvar staben skal ta krever selvtillit, ferdigheter, klinisk kunnskap og st $\varnothing$ tte fra hele behandlerteamet, samt behandlingsstrukturene rundt behandlingsstedet.

Ingen terapier eksisterer i et vakuum, og MBT for UPF bør i høy grad ikke gjøre det. For det er ikke lett å engasjere pasienter i behandling som har så mye indre smerte, og som strever så mye med å håndtere relasjonelle hendelser. Det hjelper å vite at livets mange (relasjonelle) tildragelser rammer disse mye hardere enn andre, siden de mangler en stabil og robust mentaliseringsevne. Det er

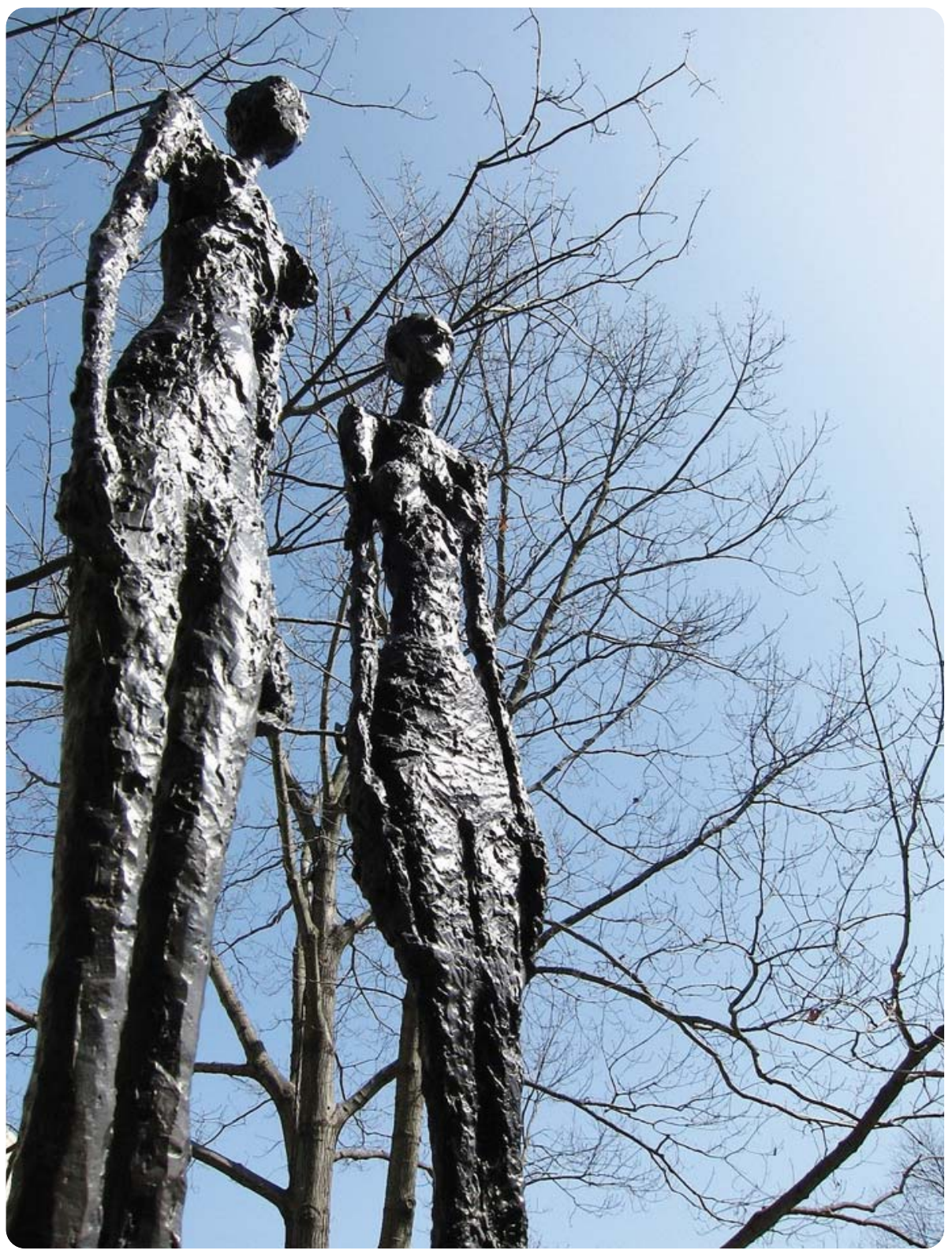

ofte den smerten de kommuniserer når de melder «at de ikke orker mer». Det er viktig at alle samarbeidspartnere som er involvert i behandling av denne pasientgruppen, er klar over dette.

Terapeuten vil uunngåelig få sin egen mentaliseringsevne redusert når en arbeider med suicidale pasienter. MBT har motvirket at dette skal bli et for stort problem, ved at pasienten både går i gruppe og i individuell terapi samtidig. Dette gjøres for å avlaste den enkelte terapeut og således fors $\varnothing \mathrm{ke}$ å redusere faren for utagering fra terapeutens side. MBT mener at slik utagering er uunngåelig, men at det her er helt vesentlig at terapeuten åpent vedkjenner seg sitt eget bidrag til det som skjer. Terapeuten må derfor være i stand til å beklage og interessert i å rydde opp i mulige misforståelser.

\section{MBT: Terapeutisk ståsted, fokus,} intervensjoner

Det viktigste en MBT-terapeut gjør i arbeidet med å engasjere suicidale pasienter, er å møte vedkommende med en mentaliserende holdning. Det handler om å ha medf $\varnothing$ lelse med pasienten, ha et fokus på vedkommendes indre verden, være interessert, nysgjerrig, autentisk og oppriktig i sitt fors $\varnothing \mathrm{k}$ på å se pasientens synspunkt.

Når det gjelder klinisk fremgangsmåte kommer det vel neppe som noen overraskelse at en MBT-terapeut hele tiden anstrenger seg for å bedre pasientens mentaliseringserne. Den overordnede målsetningen er en stabilisering av selvet, og dermed stabilisere de emosjonelle uttrykkene.

En oppnår dette primært gjennom å stille korte og enkle spørsmål, fokusere på nylige relasjonelle hendelser og ved å innta en ikke-vitende holdning. Unngå «dype» tolkninger, for mye fokus på fortiden og fremtiden, for lang stillhet, samt snirklete teorier om mulige ubevisste repetisjoner eller mulige manipulerende hensikter. Det vil bare fremmedgjøre personen.

Terapeuten må gjerne komme med sitt perspektiv, så lenge en markerer at det er sitt eget. Det er egentlig lite fancy å være MBT-terapeut. 
Her et knippe av vanlige kommentarer: «Jeg er ikke sikker på om jeg forstår, kan du hjelpe meg ved å forklare hvordan du føler det?» «Hvorfor tror du hun sa det?» «Hva skjedde?» «Hvordan føltes det?» «Det du forteller får meg til å føle meg trist. Føler du det også slik?» «Fortell mer.» «Virkelig, det var ikke min intensjon. Hva fikk deg til å tenke det? Var det noe jeg sa eller gjorde?» Alle disse vanlige sp $\varnothing$ rsmålene har til hensikt å få aktivisert pasienten selv i sin egen mentaliseringsprosess. En anbefales å være forsiktig med å gjøre denne jobben for dem.

En fremmer mentalisering ikke bare gjennom å forstå personens tilstand og fortvilelse. Empati med lidelsen og anerkjennelse av personens perspektiv på saken, er en forutsetning for en terapeutisk kontakt, men ikke tilstrekkelig for å skape forandring. Mange av forestillingene som erfares i psykisk ekvivalens blir (for) virkelige. Dessuten er det «å stå i en pre-mentaliserende modus» smertefullt. Derfor må en ikke la utsagn som kommer fra en slik posisjon passere, men aktivt stoppes og utfordres på en skjønnsom måte. Om pasienten raser videre $\mathrm{i}$ sin beretning eller virker lite interessert i å undre seg over det som skjedde, må en om nødvendig, heve armen til stoppsignal. Hensikten er å sette på «pauseknappen» og spole tilbake, slik at om pasienten for eksempel har reagert på noe terapeuten sa, så må dette tas umiddelbart. En $\varnothing$ nsker ikke å ha en samtale videre med en underliggende «umentalisert affekt», noe som ofte skjer. I de tilfellene der en ikke får fanget opp slike usnakkede misforståelser, ser en ofte selvskading rett etter en time. Om det virkelig skulle stå om livet, må en ikke gi seg mht. å utfordre forestillingene, f.eks.: "Vi kan ikke gå videre før vi har løst dette. Hvordan kan du egentlig vite at ...? Tenk om du tar feil? Slik jeg ser det...". Målsetningen med slike "stopp og stå"-intervensjoner er å få personen til å stoppe opp og tenke over/om sin egen tenkning, samt formidle at du som terapeut virkelig er engasjert i samtalen og interessert i hvordan den andre personen tenker og føler seg. En merker om

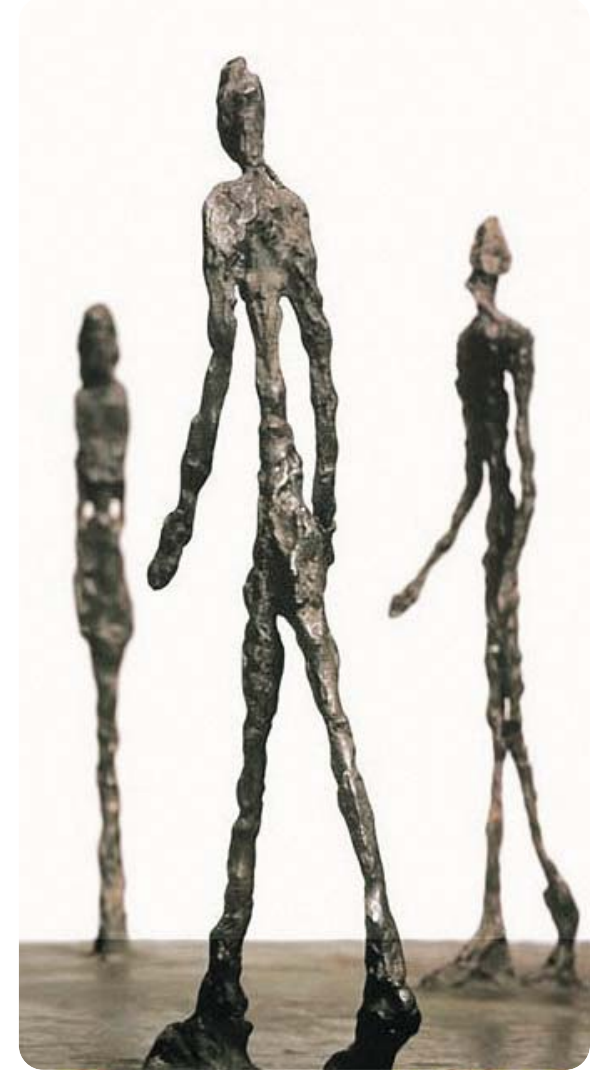

en lykkes med dette, når personen begynner å ta flere forhold i betraktning og begynner å tenke seg om. Enighet eller uenighet, påstander, beskyldninger, takknemmelighet etc. krever i seg selv ingen refleksjon, mens oppklaring av misforståelser krever bruk av mentaliseringsevnen.

MBT anbefaler at terapeuten ikke fortaper seg i innholdet i pasientens tanker, men heller fokuserer på de mentale prosessene som vedkommende har brukt for å komme frem til det vedkommende tenkte. Et klassisk MBT-spørsmål vil derfor være: «Hvordan kom du frem til det?», uansett hva dette «det» er. Det er en forenkling å si at MBT ikke er interessert i innholdet i suicidale tanker. Selvsagt er det individuelle innholdet viktig, men det er også riktig at MBT ikke ser på dette som det primære. Det er selve tenkningen som er viktig fordi det er personers manglende evne til å løse «problemet» som er problemet. En person som sier «jeg har ingen fremtid», begynner en ikke nødvendigvis å diskutere fremtiden med, men utfordrer heller ved å spørre hvordan personen er kommet frem til det. En søker altså ikke etter innsikt $\mathrm{i}$ «det egentlige», men innsikt $\mathrm{i}$ den refleksive prosessen en har brukt for å komme frem til en oppfatning.

Om en først skal gå inn på innholdet, anbefales det å fokusere på selvmordsfantasier (Gabbard, 1999, McKeon, 2009). Noen har ingen formening om hva som vil skje med dem selv eller andre etter at de er døde. Denne mangelen på narrativ om et liv for dem selv og andre etterpå er et godt utgangspunkt for mentalisering. Andre ganger finnes det konkrete fantasier, som for eksempel den hyppige forestillingen om at personen er en byrde, og at det ville vært en lettelse for alle parter om en ble borte (Joiner, 2005). Dette er ofte en grov overforenkling, da saken snarere er at om de døde, så ville det skape ulidelig smerte for de nærmeste ut livet. Problemet er at den suicidale pasient forveksler denne overforenklingen med sannheten, og at de ikke vet at de er fanget i dette perspektivet. Andre vil kunne ha fantasier om egen begravelse, hvor den underliggende intensjonen i fantasien er usikkerhet om hvorvidt noen faktisk bryr seg, noe som kan utforskes uten at en trenger å sette livet på spill. Alternativt at om en er $\mathrm{d} \varnothing \mathrm{d}$, så vil en neppe finne ut av det en lurer på. En hjelper videre personen til å mentalisere når en inviterer til en detaljert utforskning av stressende situasjoner, inkludert personens fortolkning av egen og andres mentale tilstand og motiver. Videre følger en identifikasjon av følelser og deres virkning, kontekstens betydning og en s $\varnothing$ ken etter det punktet der det kan ha oppstått mentaliseringssvikt: «Det høres ut for meg som at det var da han kom for sent hjem, at det begynte å gå nedover med deg. Hva tenkte du var grunnen til at han kom senere enn avtalt?» Grunnen til at en fokuserer på dette er at tanker opplevd i psykisk ekvivalens ofte får karakter av skråsikkerhet, noe som er selve antitesen til mentalisering. I psykisk ekvivalens er en ikke der hvor en opplever at det er forskjell mellom «å føle seg avist» og det «å være avvist», eller er i stand til å la noen antagelser fare. Her ligger altså "djevelen i detaljene". 
En $u$ tfordrer mentaliseringssvikt ved å peke på mulige alternative tolkninger, og ved å legge fokuset på den indre verden, ikke så mye på atferd, ytre forhold eller mestring. Det er viktig å huske på at vi ikke var tilstede, og for alt vi vet, så har personen rett i sine (mis)tanker. Vår oppgave er ikke å forskjønne virkeligheten, få personen til å føle at de ikke har rett til sine tanker og følelser eller innbille dem at de har misforstått alt, men kort og godt å få dem til å mentalisere bedre rundt det som har hendt.

En annen anbefaling er det MBT kaller "motsatte bevegelser". Hensikten er å få pasienten til å begynne å mentalisere igjen, om vedkommende er låst i ett perspektiv eller i et "foretrukket modus". Om personen f.eks. snakker mye om seg selv, kan du skifte perspektiv til hvordan dette påvirker andre i vedkommendes nærhet. Der hvor pasienten snakker mye om andre, kan du dreie samtalen mer i retning av hvordan dette opplevdes for pasienten. Snakker pasienten mye om følelser, skifter du fokus til tanker og refleksjon og motsatt. Snakker personen mye om handlinger, retter du fokus om hvilke ulike motiver som kan ligge bak etc. Er det for hett i relasjonen med terapeuten, kan du skifte til mer ytre hendelser, og motsatt. En mer omfattende fremstilling av ulike MBT-intervensjoner, finnes i en nylig publisert bok (Karterud \& Bateman, 2011).

\section{Oppsummering}

På tross av viktigheten av å engasjere suicidale pasienter gjennom differensierte risikovurderinger, en "markert" behandlingsstruktur, en mentaliserende holdning og fokusert MBT-teknikk, så anser MBT selve tilknytningsprosessen mellom pasient og terapeut som det viktigste elementet i behandlingen. De første elementene er viktige, men først og fremst i den grad de vil kunne bidra til å fasilitere mentalisering av den terapeutiske relasjon. For psykisk smerte forbundet med suicidale tilstander blir best avhjulpet gjennom tilstedeværelsen av en tilknytningsperson som bidrar til at personen ikke føler seg alene, og som hjelper til med å lage et eller flere narrativ som skaper sammenheng og koherens til et indre sammenbrudd. Terapeuten må i denne prosessen være spesielt oppmerksom på de helt spesielle problemene disse har, og ha et våkent фye for og ta et ansvar for, den affektive temperaturen $\mathrm{i}$ det interpersonlige feltet, slik at det blir mulig å tenke og reflektere.

MBT er en terapiform som eksplisitt fremhever nødvendigheten av terapeutens engasjement. En ting er å anstrenge seg for å engasjere pasienten i seg selv, sine relasjoner og i den terapeutiske prosess, herunder forståelse og håndtering av selvmordsproblematikk. Like viktig er det at terapeuten selv er genuint engasjert i slike suicidale tilstander, og er i stand til å holde denne interessen oppe selv når det er som vanskeligst. Således engasjerer du suicidale pasienter i behandling ved selv å holde din nysgjerrighet åpen, fleksibel og utfordrende.

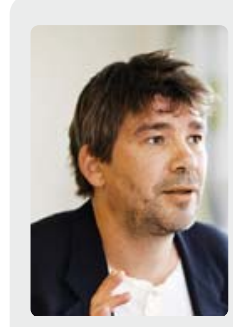

Christian Schlüter arbeider som psykologspesialist ved Avdeling for Personlighetspsykiatri, Oslo Universitets sykehus, Ullevål. Interesseeltene er personlighetsforstyrrelser, differensialdiagnos tikk og dynamisk psykoterapi. 2003 skrev han sammen med Sigmund Karterud boken "Selvets Mysterier", som handler om Hamsun's "Mysterier" basert på en selvpsykologisk tolkning.

\section{Referanser}

Allen, J.G. 2006. Mentalizing In Practice. I Allen J.G, Fonagy, P. (ed.): Handbook of Mentalization Based Treatment. Chichester, UK, Wiley.

Brodsky et al. (2006). Interpersonal precipitants and suicide attempts in borderline personality disorder. Suicide Life Threat Behavior, 36: 313-322.

Bateman, A., \& Fonagy, P. (2004). Psychotherapy for borderline Personality Disorder: Mentalization-Based Treatment. Oxford, UK, Oxford University Press.

Bateman, A. \& Fonagy, P. (2006a). Mentalization Based Treatment for Borderline Personality Disorder: A Practical Guide. Oxford, UK, Oxford University Press.

Bateman, A. \& Fonagy, P. (2008). 8-Year FollowUp of Patients Treated for Borderline Personality Disorder: Mentalization-Based Treatment Versus Treatment as Usual. Am J Psychiatry, 165, 631-638.
Bateman, A. \& Fonagy, P. (2011). Handbook of Mentalizing in Mental Health Practice. American Psychiatric Publishing, Inc. London, England.

Clarkin, J.F., Yeomans,F.E., \& Kernberg, O. (2006). Psychotherapy for Borderline Personality. Focusing on object relations. American Psychiatric Publishing, Inc.

Dimaggio, G., Semerari, A., Carcione A., et al. (2007). Psychotherapy of Personality Disorders: Metacognition, States of mind and Interpersonal Cycles. New York, Routledge.

Fonagy, P., Gergely, G., Jurist, E., \& Target, M. (2002). Affect Regulation, Mentalization and the Development of the Self. New York: Other Press.

Gabbard, G. (1999). Psychotherapy Strategies and the Chronically Suicidal Patient. Psychiatric. Times, Vol. 16 No 7.

Joiner, T. (2005). Why People Die By Suicide? Harvard University Press.

Karterud, S., \& Bateman, A. (2010). Manual for mentaliseringsbasert terapi (MBT) og MBT vurderingsskala. Versjon individualterapi. Gyldendal Akademisk.

Karterud, S., \& Bateman, A. (2011). Manual for mentaliseringsbasert psykoedukativ gruppeterapi (MBT-1). Gyldendal Akademisk.

Linehan, M. (1993). Cognitive-Behavioral Treatment of Borderline Personality Disorder. Guilford Press.

McKeon, R. (2009). Suicidal Behavior. Gøttingen: Hogrefe \& Hubér.

McWillams, N. (2011). Psychoanalytic Diagnosis. Understanding Personality Structure in the Clinical Process. Second edition. Guilford Press.

Mehlum, L., Friis, S., Vaglum, P., \& Karterud, S. (1994). The longitudinal pattern of suicidal behavior in borderline personality disorder. A prospective follow-up study. Acta Psychiatrica Scandinavica, 90, 124-30.

Nygren, P., \& Skårderud, F. (2008). Mentalisering som sosial kompetanse hos barn og unge. I P.

Nygren \& H. Thuen (red.). Barn og unges kompetanseutvikling. Oslo: Universitetsforlaget.

Paris, J. (2006). Half in Love with Death. Managing the Chronically Suicidal Patient. Lawrence Erlbaum Associates.

Rydén, G., \& Wallroth, P. (2008). Mentalisering - att leka med verkligheten. Natur \& Kultur.

Skodol A.E., Gunderson J.G., Shea, M.T., et al. (2006). The Collaborative Longitudinal Personality Disorder Study (CLPS): overview and implications. J. Pers Disord, 19, 487-504.

Young, J., Klosko, J. S., Weishaar, M.E. (2003). Schema Therapy. A Practitioner's Guide. The Guilford Press.

Skulpturene gjengitt på bildene er laget av den sveitsisk billedhuggereren, tegneren og grafikeren Alberto Giacometti (1901-1966). 